\title{
PERCEPTION, IMPACT AND DETERMINANTS OF CLIMATE CHANGE ADAPTATION AMONG VEGETABLE GROWERS OF DHADING DISTRICT OF NEPAL
}

\author{
B.R. Dahal ${ }^{1 *}$, B. Shrestha ${ }^{1}$ and J. Shrestha ${ }^{2}$ \\ ${ }^{1}$ Agriculture and Forestry University, Rampur,Chitwan, Nepal \\ ${ }^{2}$ Nepal Agriculture Research Council, Agriculture Botany Division, \\ Khumaltar, Lalitpur, Nepal
}

\begin{abstract}
Climate change is one of the most challenging problems for the agricultural development. The purpose of this study is to analyze perception of climate change, its impacts and determinants among vegetable growers and to identify major adaptation strategies used by them. The study was based on survey of 75 vegetable growers; 34 from Benighat Rorang rural municipality and 41 from Siddhalek rural municipality of Dhading district of Nepal. Data were collected using face to face interview. The study provided empirical evidence of decreased in intensity, duration and frequency of rainfall and increase in annual temperature, drought duration and frost severity. Incidence of disease and pest, decline in soil fertility, scarcity of water and severe frost/hailstones were major problems. The $45.33 \%$ vegetable growers were compelled to change planting and $54.67 \%$ of them to change harvesting due to climate change effect. The adaptation practices such as mulching (24\%), green/plastic house (29.3\%), drip irrigation (8\%), IPM $(12.5 \%)$, change in crop variety $(31.3 \%)$ and cropping pattern were found common practices adopted by farmers. The probability of adapting climate change mitigating factors was $70.26 \%$ higher for those who had received training in vegetable cultivation. Use of new climate smart agricultural technologies and providing training about vegetable cultivation were found suitable strategies to mitigate the negative impacts of climate change.
\end{abstract}

Keywords: Climate smart agriculture, Cropping pattern, IPM, Soil fertility

\section{INTRODUCTION}

Climate change is change in state of the climate over time, whether due to natural variability or as a result of anthropogenic activities (IPCC, 2007). Climate change has

* Corresponding author: dahalbhishmaraj@gmail.com 
been taking place since the origin of the earth as a natural process but in recent years due to uncontrolled human anthropogenic activities, climate change is speeding at an alarming rate. Despite its own meager contribution to green house gas $(0.027 \%)$, Nepal ranked $4^{\text {th }}$ vulnerable nation to climate change (Sapkota and Rijal, 2016). Location of Nepal at centre of Himalaya enlightened the fact that it is major target point of climate change impact. Rapid temperature rise $\left(>0.06^{\circ} \mathrm{C}\right)$, retreating glaciers $(>30 \mathrm{~m}$ per year), erratic rainfall and increase in frequency of natural disaster like flood and landslide are major effect of climate change seen in recent years (Karki et al., 2009).

Agriculture contributes to one third of national GDP, change in climatic parameters like rainfall, temperature, solar radiation imparted great threat to cropping system. Increase in temperature and dropping of rainfall amount accelerates evapotranspiration, increase demand of water by many folds. Climatic parameters like, high temperature, rainfall and humidity are favorable for reproduction of pathogen and insects which increase disease spread in crops (Malla, 2008). Erratic rainfall pose abrasive effect on top soil, flood and landslide takes off top soil making on site deficit in nutrients required for better crop growth. Increase in frost duration and severity force plant to face many physiological and bio-chemical disorder which ultimately reduce crop productivity. Scarcity of water, spread of disease pest, decline

in soil fertility, frost injuries and drought are some of the major problems seen in Nepalese agriculture (Malla, 2008).

Vegetables are important crops in Nepal as they are rich source of nutrients and give higher return to farmers of Kavre, Dhading, Chitwan, Makwanpur and Nuwakot (MoAD, 2017). Productivity of Vegetables is increasing but the rate of increment is far beyond the rate of demand (MoAD, 2017). At the same time, climate change is adding problems in vegetable farming as farmers are unaware about adaptation of climate change mitigating factors. Therefore, a study was undertaken to figure out perception, impacts and determinants of climate change adaptation among vegetable growers of Dhading district.

\section{METHODOLOGY}

The study was conducted in Dhading, part of province No. 3 of Federal Republic of Nepal. Dhading was purposively selected because it is major vegetable producing district of Nepal with identifiable number of vegetable growing farmers. The district spreads from 27'40" E to $28^{\prime} 17^{\prime \prime} \mathrm{E}$ and $80^{\prime} 17^{\prime \prime} \mathrm{N}$ to $84^{\prime} 35^{\prime \prime} \mathrm{N}$. Climate here ranges from tropical, subtropical, temperate, sub-alpine and alpine but subtropical is dominant. 75 vegetable growers were randomly selected, 41 from Siddhaek and 34 from Benighat Rorang rural municipalities of Dhading. Face to face interview method was used to collect primary data using pretested semi-structured questionnaire in the month of January 2019. Data about perception, impact and adaptation strategies followed by farmers since past 10 years were taken during the study. Two Focus Group 
Discussion (FGD) and key informant interview (KII) were conducted to validate information obtained from respondents. Data analysis and comparisons were made to obtain results. The data were entered in Microsoft Excel, SPSS and analysis was done by using SPSS and STATA.

\section{Probit model}

Probit model was used to determine the factors that influence farmers to follow climate change adaptation strategies in Dhading district. Probit model is statistical probability model with two categories in the dependent variable (Liao, 1994) cited by Dahal and Rijal (2019). Probit model is based on the cumulative normal probability distribution. The binary dependent variable, $y<$ takes on the values of zero and one. In binary probit model, farmers following climate change mitigating factors is taken as 1 , while those who do not follow is taken as zero. It is assumed that the $\mathrm{i}^{\text {th }}$ farmers obtains maximum utility, it has climate change adaptation preference over non adaptation. The probability $\mathrm{Pi}$ of choosing any alternative over not choosing can be shown by following equation, where $\varphi$ represents the cumulative distribution of the standard normal random variable (Uzunoz and Akcay, 2012).

$\mathrm{P}_{\mathrm{i}}=\operatorname{prob}\left[\mathrm{Y}_{\mathrm{i}}=1 \mathrm{lxl}=\int_{-\infty}^{x i^{\prime} \beta}\left(2 \pi^{\frac{-1}{2}} \exp \left(-\frac{t^{2}}{2}\right) \mathrm{dt}=\varphi\left(\mathrm{x}_{\mathrm{i} \beta}^{\prime}\right)\right.\right.$

\section{RESULTS}

\section{Perception of vegetable growers towards climate change}

According to the study conducted in Siddhalek rural municipality and Benighat Rorang rural municipality of Dhading district, nearly a half (46.67\%) of farmers had no idea about climate change but $53.33 \%$ farmers were cognizant about climate change. Source of information about climate change among conscious farmers was media/news and school. Very few conscious farmers (15) got knowledge of climate change through their self-experience.

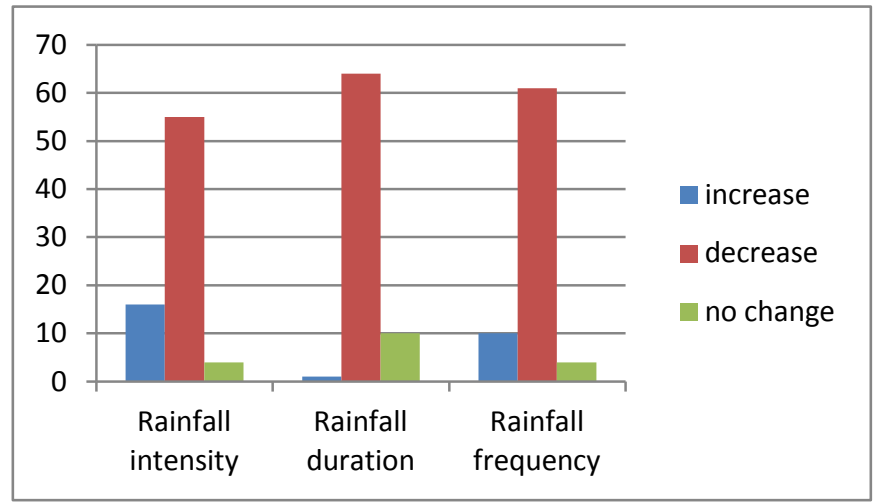

Figure 1. Perception of farmers towards rainfall 
Most of the respondents perceived decrease in all the three rainfall parameters, intensity, duration and frequency (fig. 1). 55 (73.3\%), 64 (85.5\%) and $61(81.3 \%)$ of the respondents perceived decreased in rainfall intensity, duration and frequency respectively.

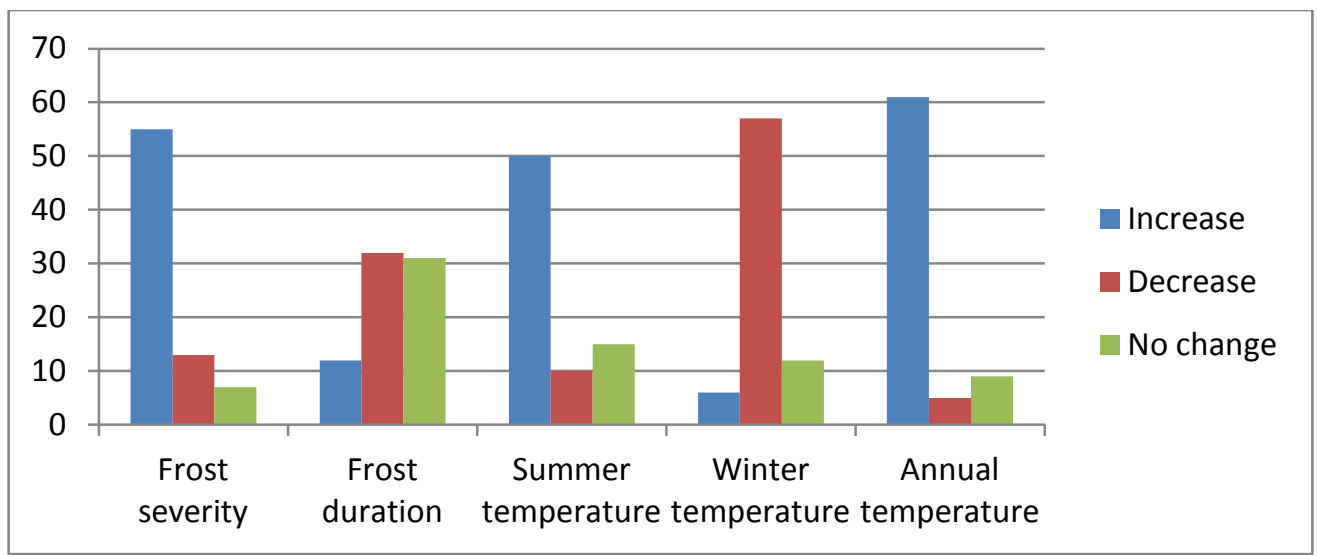

Figure 2. Perception of farmers towards frost and temperature

According to the survey, most of the respondents (73.3\%) perceived increase in frost severity while frost duration was either decreasing $(42.7 \%)$ or constant $(41.3 \%)$. Very few farmers thought about decreasing pattern of frost severity (17.3\%) and increasing pattern of frost duration (16.0\%). The survey revealed that, $50(66.7 \%)$ of farmers perceived increase in summer temperature, $15(20.0 \%)$ thought there was no change in summer temperature and $10(13.33 \%)$ perceived that summer temperature was decreasing. Majority of farmers $(57.0 \%)$ became cognizant about further decreasing pattern of winter temperature whereas very few $(8 \%)$ of farmers deduced winter temperature was in increasing trend. In contrast to decreasing summer temperature, majority of farmers $(81.33 \%)$ comprehended increasing trend of annual temperature. Very few respondents $(6.67 \%)$ perceived that annual temperature is decreasing (Fig. 2) 
Table 1. perception of farmers towards flood, drought and hailstones

\begin{tabular}{|c|c|c|c|c|c|}
\hline \multirow[b]{2}{*}{ Flood frequency } & \multicolumn{3}{|c|}{ Farmer's category } & \multirow{2}{*}{$\begin{array}{l}\text { Chi-square } \\
\text { value }\end{array}$} & \multirow[b]{2}{*}{$\mathrm{P}$-value } \\
\hline & Overall & Siddhalek & Benighat Rorang & & \\
\hline Increase & $24(32.0)$ & $11(26.8)$ & $13(38.2)$ & $146.385^{* * *}$ & 0.00 \\
\hline Decrease & $40(53.3)$ & $23(56.1)$ & $17(50.00)$ & & \\
\hline No change & $11(14.7)$ & $7(17.1)$ & $4(11.8)$ & & \\
\hline \multicolumn{6}{|l|}{ Drought duration } \\
\hline Increase & $67(89.3)$ & $39(95.1)$ & $28(82.4)$ & $3.853^{\text {ns }}$ & 0.146 \\
\hline Decrease & $2(2.7)$ & $0(0.00)$ & $2(5.9)$ & & \\
\hline No change & $6(8.0)$ & $2(4.9)$ & $4(11.8)$ & & \\
\hline \multicolumn{6}{|l|}{ Hailstones frequency } \\
\hline Increase & $45(60.0)$ & $31(75.6)$ & $14(41.2)$ & $9.823^{* * * *}$ & 0.007 \\
\hline Decrease & $21(28.0)$ & $8(19.5)$ & $13(38.2)$ & & \\
\hline No change & $9(12.0)$ & $2(4.9)$ & $7(20.6)$ & & \\
\hline
\end{tabular}

Note: $* * *$ indicate significant at $1 \%$ level of significance and ns indicate non-significant

According to the field survey, $26.8 \%$ farmers of Siddhalek and $38.2 \%$ farmers of Benighat thought that frequency of flood had increased. $56.1 \%$ respondents of Siddhalek and $50.0 \%$ of respondents comprehended that flood frequency had decreased since last ten years. Very few farmers $(14.7 \%)$ perceived that there was no change in flood frequency. Most of the farmers (89.3\%) perceived increase in drought duration. Majority of respondents thought that hailstones frequency was increasing, $75.6 \%$ respondents of Siddhalek and $41.2 \%$ respondents of Benighat perceived increasing trend of hailstones frequency (Table 1)

\section{Impact of climate change on vegetable crops}

Table 2. Impact of climate change in planting and harvesting

\begin{tabular}{l|l|l|l|l|l}
\hline Shift in planting & Overall & Siddhalek & Benighat Rorang & Chi-square value & P-value \\
\hline Early & $13(17.3)$ & $10(24.4)$ & $3(8.8)$ & $153.522^{* * * *}$ & 0.00 \\
Delay & $21(28.0)$ & $8(19.5)$ & $13(38.2)$ & & \\
No shift & $41(54.6)$ & $23(56.1)$ & $18(52.9)$ & & \\
Shift in harvesting & & & & \\
Early & $11(14.7)$ & $7(17.1)$ & $4(11.8)$ & & \\
Delay & $30(40.0)$ & $16(39.0)$ & $14(41.2)$ & \\
No change & $34(45.3)$ & $18(53.9)$ & $16(47.1)$ & & \\
\hline
\end{tabular}

Note: $* * *$ indicate significant at $1 \%$ level of significance 
According to the study, climate change had forced majority of farmers to shift planting and harvesting times. Among all farmers, $28.0 \%$ and $17.3 \%$ cultivate vegetables ( Table 2) early and late than usual practice respectively. Unusual weather pattern had forced farmers to alter harvesting time, $40 \%$ of farmers made delayed harvest whereas $14.7 \%$ harvested earlier than usual practice.

Table 3. Impact of climate change in crop productivity and area

\begin{tabular}{l|l|l|l|l|l}
\hline Crop productivity & Overall & Siddhalek & Benighat Rorang & Chi-square value & P value \\
\hline Increase & $29(38.6)$ & $17(41.5)$ & $12(35.3)$ & $146.252^{* * * *}$ & 0.00 \\
Decrease & $20(26.7)$ & $12(29.3)$ & $8(23.5)$ & \\
No change & $26(34.7)$ & $12(29.3)$ & $14(41.2)$ & \\
Area & & & & \\
Increase & $46(61.3)$ & $26(63.4)$ & $20(58.8)$ & $149.692^{* * *}$ & 0.00 \\
Decrease & $15(20.00)$ & $10(24.4)$ & $5(14.7)$ & & \\
No change & $14(18.70)$ & $5(12.2)$ & $9(26.5)$ & & \\
\hline
\end{tabular}

Note: $* * *$ indicate significant at $1 \%$ level of probability.

Based on field survey on impacts of climate change, $38.6 \%$ farmers thought that crop productivity was increasing but $34.7 \%$ farmers said that there was no change in crop productivity (Table 3). Among all farmers, $61.3 \%$ farmers expanded the area of vegetable farming, $20 \%$ of farmers reduced the area of vegetable farming. Despite rapid urbanization and fragmentation of land, the increase in area of vegetable farming is due to the increasing demand of vegetables.

Climate change had negative effect on crop growth and development. This might be due to disturbance in bio-chemical and physiological processes of plants. 56\% of respondents perceived that nursery stage is severely affected followed by fruit development (16\%), vegetative growth (14.67\%) and transplanting $(10.67 \%)$ whereas ripening was least affected by climate change. All the farmers (100\%) perceived that sources of water were declining at alarming rate, which was due to increase in deforestation, pollution and decrease in rainfall. $82.67 \%$ vegetable growers said that soil fertility was declining; this might be due to long term application of chemical fertilizers. The decline in soil fertility was due to increase in erosion caused by erratic rainfall, flood and landslide.

According $78.67 \%$ of total farmers, disease spread was increasing in the area since last decade, in contrast to that very few farmers $(21.33 \%)$ perceived that disease spread was same as before. Climate change parameters had direct impact on the development and distribution of pests and diseases. Various types of diseases were seen in the study area, the following was seen frequently. (Table 4) 
Table 4: Disease/pest in the area

\begin{tabular}{|c|c|c|c|c|}
\hline Vegetable Crops & Disease/Pests & $\begin{array}{c}\text { Pest } \\
\text { category }\end{array}$ & Scientific name & $\begin{array}{c}\text { Farmer's } \\
\text { name }\end{array}$ \\
\hline Tomato & Blight (Early and late) & Fungi & $\begin{array}{l}\text { Alternaria solani } \\
\text { Phytophthora infestans }\end{array}$ & $\begin{array}{l}\text { Dadhuwa } \\
\text { rog }\end{array}$ \\
\hline \multirow[b]{2}{*}{ Potato } & $\begin{array}{l}\text { Whitefly } \\
\text { Tomato leaf miner }\end{array}$ & $\begin{array}{l}\text { Insecta } \\
\text { Insecta }\end{array}$ & $\begin{array}{l}\text { Bemisia spp } \\
\text { Tuta absoluta }\end{array}$ & $\begin{array}{l}\text { Setojhinga } \\
\text { Putali }\end{array}$ \\
\hline & $\begin{array}{l}\text { Blight (Early and late) } \\
\text { Fungus attack }\end{array}$ & $\begin{array}{l}\text { Fungi } \\
\text { Fungi }\end{array}$ & $\begin{array}{l}\text { A. solani and } P \text {. } \\
\text { infestans } \\
\text { Fusarium spp. } \\
\text { Pythium spp. }\end{array}$ & $\begin{array}{l}\text { Dadhuwa } \\
\text { rog } \\
\text { Dhusi }\end{array}$ \\
\hline \multirow{3}{*}{$\begin{array}{l}\text { Cauliflower and } \\
\text { cabbage }\end{array}$} & $\begin{array}{l}\text { Potato wilt } \\
\text { Red ants }\end{array}$ & $\begin{array}{l}\text { Bacteria } \\
\text { Insecta }\end{array}$ & $\begin{array}{l}\text { Pseudomonas } \\
\text { solanacearum } \\
\text { Dorylus orientalis }\end{array}$ & $\begin{array}{l}\text { Pat galne } \\
\text { rog } \\
\text { Ratokamila } \\
\end{array}$ \\
\hline & $\begin{array}{l}\text { Diamond Back } \\
\text { Moth(DBM) }\end{array}$ & Insecta & Plutella xylostella & $\begin{array}{l}\text { Itta butte } \\
\text { putali }\end{array}$ \\
\hline & Alternaria leaf spots & Fungi & $\begin{array}{l}\text { Alternaria brassicae } \\
\text { A. brassicicola }\end{array}$ & Thople rog \\
\hline \multirow[b]{2}{*}{ Cucurbits } & Powdery mildew & Fungi & Erysiphe cruciferarum & Kharane rog \\
\hline & Powdery mildew & Fungi & $\begin{array}{l}\text { Erysiphe spp } \\
\text { Podosphaera xanthii }\end{array}$ & Kharane rog \\
\hline \multirow{3}{*}{ Leafy vegetables } & $\begin{array}{l}\text { Green Stink bug } \\
\text { Fruit fly } \\
\text { Discoloratio after post } \\
\text { harvest }\end{array}$ & $\begin{array}{l}\text { Insecta } \\
\text { Insecta } \\
\text { Physiologi }\end{array}$ & $\begin{array}{l}\text { Chinaviahalaris } \\
\text { Bactrocera cucurbitae }\end{array}$ & $\begin{array}{l}\text { Patero } \\
\text { Jhinga }\end{array}$ \\
\hline & Aphids & insecta & $\begin{array}{l}\text { Myzus persicae } \\
\text { Aphis spp. }\end{array}$ & Lahi \\
\hline & Damping off & Fungi & $\begin{array}{l}\text { Fusarium spp. } \\
\text { Pythium spp. } \\
\text { Rhizoctonia } \text { spp. }\end{array}$ & Phedkuhine \\
\hline \multirow[b]{2}{*}{ Okra } & Powdery mildew & Fungi & Erysiphe polygoni & $\begin{array}{l}\text { Kharane } \\
\text { Rog }\end{array}$ \\
\hline & $\begin{array}{l}\text { Jassids } \\
\text { Fruit and shoot borer }\end{array}$ & $\begin{array}{l}\text { Insecta } \\
\text { Insecta }\end{array}$ & $\begin{array}{l}\text { Amrasca } \\
\text { biguttulabiguttula } \\
\text { Earias vittela } \\
\text { E. insulana } \\
\end{array}$ & \\
\hline Bitter gourd & Fruit fly & insecta & Bactrocera dorsalis & Jhinga \\
\hline
\end{tabular}




\section{Adaptation strategies of climate change at farmers' level}

Table 5. Adaptation strategies for water scarcity at farmers' level

\begin{tabular}{lllll|l|l}
\hline Variables & & Siddhalek & Benighat Rorang & Chi-square value & P-value \\
\hline Drip irrigation & $6(8.0)$ & $3(7.3)$ & $3(8.8)$ & $144.11^{* * *}$ & 0.00 \\
Store rain water & $18(24.0)$ & $14(34.1)$ & $4(11.8)$ & $153.801^{* * *}$ & 0.00 \\
Mulching & $18(24.0)$ & $14(34.1)$ & $4(11.8)$ & $5.105^{* *}$ & 0.024 \\
\hline
\end{tabular}

Note: ** and $* * *$ indicate significance at $5 \%$ and $10 \%$ levels of probability

Drought was one of major problems among vegetable growers of Dhading. Very few respondents $(8 \%)$ adopted drip irrigation to get rid from water scarcity. The $34.1 \%$ of respondents of Siddhalek and $11.8 \%$ respondent of Benighat stored rain water (Table 5). They stored water by making artificial pond in which water infiltration was sealed off by thick plastic. 24\% of the respondents adopted mulching for soil moisture conservation. Problems of higher temperature during summer were managed by applying adequate amount of water.

Table 6. Adaptation strategies for frost at farmer's level

\begin{tabular}{llllll}
\hline Variables & Overall & Siddhalek & Benighat Rorang & Chi-Square value & P-value \\
\hline Frost tolerant varieties & $0(0)$ & $0(0)$ & $0(0)$ & 144.000 & 0.00 \\
Plastic/Green house & $22(29.3)$ & $8(19.5)$ & $14(41.2)$ & $152.080^{* * *}$ & 0.00 \\
Mulching & $13(17.3)$ & $8(19.5)$ & $5(14.7)$ & $144.575^{* * *}$ & 0.00 \\
\hline
\end{tabular}

Note: $* * *$ indicate significant at $1 \%$ level of probability

None of the farmers of the study area used frost tolerant variety. $19.5 \%$ respondents of Siddhalek and $41.2 \%$ of respondents of Benighat Rorang cultivated vegetable under green/plastic house. $19.5 \%$ farmers of Siddhalek and $14.7 \%$ respondents of Benighat used mulching to prevent plants from frost (Table 6).

Table 7. Adaptation to disease and pests at farmer's level

\begin{tabular}{l|l|l|l|c|c}
\hline \multicolumn{1}{c|}{ Variables } & Overall & Siddhalek & $\begin{array}{c}\text { Benighat } \\
\text { Rorang }\end{array}$ & $\begin{array}{c}\text { Chi-square } \\
\text { value }\end{array}$ & $\begin{array}{c}\text { P- } \\
\text { value }\end{array}$ \\
\hline $\begin{array}{l}\text { Collecting and burning } \\
\text { crop residue }\end{array}$ & $11(14.6)$ & $9(22.0)$ & $2(5.9)$ & $151.362^{* * *}$ & 0.00 \\
$\begin{array}{l}\text { Use of trap crop } \\
\begin{array}{l}\text { Use of different physical } \\
\text { traps }\end{array}\end{array}$ & $\begin{array}{l}21(28.0) \\
\text { Biological management }\end{array}$ & $10(24.4)$ & $11(32.4)$ & $145.122^{* * *}$ & 0.00 \\
\hline
\end{tabular}


Climate change has resulted in spread of diseases and pests (Table 7), in some cases new types of diseases were also seen. For management of disease and pests, about $60 \%$ of farmers used chemicals, $24 \%$ of farmers used IPM method and $16 \%$ did not adapt any methods $22 \%$ and $5.9 \%$ farmers of Siddhalek and Benighat Rorang collected and burnt crop residue. The $24.4 \%$ farmers of Siddhalek and $32.4 \%$ farmers of Benighat Rorang used trap crop for management of insects. They had cultivated few rows of marigold to control nematode in vegetable. Among IPM practice, majority of farmers used physical traps for monitoring and controlling insects. They used pheromone trap, sticky traps for management of insects like fruit fly, thrips, aphids etc. Very few farmers of the study area followed biological management to control insects and pests. Most of the respondents had no idea about such system of management.

Table 8/ Adaptation to declining soil fertility at farmer's level

\begin{tabular}{|c|c|c|c|c|c|}
\hline Variables & Overall & Siddhalek & $\begin{array}{l}\text { Benighat } \\
\text { Rorang }\end{array}$ & $\begin{array}{l}\text { Chi-square } \\
\text { value }\end{array}$ & $\begin{array}{l}\mathrm{P}- \\
\text { value }\end{array}$ \\
\hline $\begin{array}{l}\text { Animal } \\
\text { application }\end{array}$ & $73(97.3)$ & $39(95.1)$ & $34(100.0)$ & $147.272^{* * *}$ & 0.00 \\
\hline Compost making & $12(16.0)$ & $5(12.2)$ & $7(20.6)$ & $145.870^{* * *}$ & 0.00 \\
\hline Crop rotation & $38(50.6)$ & $17(41.5)$ & $21(61.8)$ & $149.880^{* * *}$ & 0.00 \\
\hline $\begin{array}{l}\text { Retaining crop residue } \\
\text { back to soil }\end{array}$ & $43(57.3)$ & $20(48.8)$ & $23(67.6)$ & $149.193^{* * *}$ & 0.00 \\
\hline Cultivate in new land & $24(32.0)$ & $16(39.0)$ & $8(23.5)$ & $147.938^{* * *}$ & 0.00 \\
\hline
\end{tabular}

Note: $* * *$ indicate significance at $1 \%$ level of probability

Almost all the farmers applied chemical fertilizers but they had created serious threat to agro-ecology accelerating climate change. Climate change deteriorated soil fertility status, various techniques had been adopted by farmers to mitigate soil fertility decline. $97.3 \%$ of the vegetable growers applied animal manure to restore soil fertility. $12.2 \%$ farmers of Siddhalek and 20.6\% farmers of Benighat Rorang applied compost manure. $41.5 \%$ respondents of Siddhalek and $61.8 \%$ respondents of Benighat Rorang practiced crop rotation with legumes. Leguminous crops were proven to be beneficial for improving soil properties. Most of the farmers $(57.3 \%)$ of the study area retained crop residue back to soil. $32 \%$ of the vegetable growers of the study area cultivated in new land to acclimatize with climate change (Table 8) 


\section{Determinants of climate change adaptation}

Table 9. Determinants of climate change adaptation

\begin{tabular}{lllcll}
\hline Variables & Coefficients & Standard Error & $\mathrm{Z}$ & $\mathrm{p}>|\mathrm{Z}|$ & $\mathrm{dy} / \mathrm{dx}$ \\
\hline Family type (@) & -0.318517 & 0.3623098 & -0.88 & 0.379 & -0.0809646 \\
Gender of Household head (@) & 0.4643503 & 0.3893749 & 1.19 & 0.233 & 0.1180342 \\
Age of household head ( years) & -0.0044903 & 0.3893749 & -0.16 & 0.871 & -0.0011414 \\
$\begin{array}{l}\text { Schooling of household head } \\
\text { (years) }\end{array}$ & 0.0979612 & 0.0539266 & 1.82 & 0.069 & 0.024901 \\
$\begin{array}{l}\text { Occupation of household head } \\
\text { (@) }\end{array}$ & -0.1363144 & 0.3935561 & -0.35 & 0.729 & -0.0346501 \\
Training received (@) & 0.7064034 & 0.3978305 & 1.78 & 0.076 & 0.1795623 \\
Access to extension (@) & 0.2236322 & 0.4372344 & 0.51 & 0.609 & 0.0568456 \\
Farmers group (@) & 0.1834821 & 0.4364304 & 0.42 & 0.674 & 0.0466397 \\
Constant & -0.0591375 & 1.559597 & -0.04 & 0.97 & \\
\hline
\end{tabular}

Probit model was used to assess the factor influencing the adaptation of climate change. Good explanatory power of the model was revealed through likelihood ratio chi-square $\left(\mathrm{LR} \mathrm{chi}^{2}\right)$. LR chi ${ }^{2}$ was found to be statistically significant at $1 \%$ level of probability and the pseudo $\mathrm{R}^{2}$ was 0.0099 . Among eight variables included in this model, schooling of household head and training received was found to be statistically significant at $10 \%$ level of probability. It had been found that farmers who had received training about vegetable cultivation and farmers with higher schooling were more likely to adapt climate change mitigating factors. Probability of adaptation of climate change strategies was $9.7 \%$ higher for farmers who had good education (Table 9). Similarly, the probability to adapt climate change strategies was $70.6 \%$ higher for farmers who had received training in vegetable cultivation. Other variables like gender of household head, membership of farmers group, and access to extension had positive relation with adaptation of climate change strategies. Occupation of household head, gender of household age and family type had negative relation with adaptation of climate change strategies.

\section{DISCUSSION}

The findings of this study showed that nearly a half $(46.67 \%)$ of the farmers had no idea about climate change. Most of the farmers perceived decreased in intensity, duration and frequency of rainfall and increase in annual temperature, drought duration and frost severity. Incidence of diseases and pests, decline in soil fertility, scarcity of water and severe frost/hailstones were major problems faced by vegetable growers. Pre-monsoon and monsoon rainfall were increasing but post monsoon rainfall was decreasing in central hills of Nepal. Overall wet days were decreasing and dry days were increasing across the country (Karki et al., 2017). Decreasing in 
intensity, frequency and duration of rainfall are in consistent with rainfall of mountainous region of Makawanpur (Subedi, 2018). Devkota (2014) found that there was increasing trend of summer, winter and annual temperature. The decreasing flood frequency was observed in survey conducted by Subedi (2018) in Makawanpur but in contrast with flood pattern of Nepal (Gaire et al., 2015). Trend analysis of drought in central Nepal showed that drought intensity, severity and duration were strongly increasing (Dhakal et al., 2016). River water resources were increasing in Nepal due to melting of mountainous ice but drinking and irrigation water were declining (Basyal, 2017). River water is unfit for drinking and there is poor infrastructure to lift river water for irrigation in Nepal. Farmers were forced to change planting and harvesting time. The shift in planting and harvesting time had been found in mountainous agricultural farming system of central hills of Nepal (Subedi, 2018). The study showed that $38.6 \%$ farmers thought that crop productivity was increasing due to climate change. Despite climate change, productivity of vegetable was in increasing trend this might be due to adoption of new technology in vegetable farming like high yielding varieties, mulching, disease and pest management, cultivation under green house and so on (Pandey et al., 2017). Similar increasing trend of crop productivity was observed by Subedi (2018) and MoAD (2017). It had been found that farmers who had received training about vegetable cultivation and farmers with higher schooling were more likely to adapt climate change mitigating factors. Mulching and drip irrigation are the measure to get rid from scarcity of water resources. Mulching was used in mountainous region of Makawanpur to conserve soil moisture (Subedi, 2018). Drip irrigation increase water use efficiency reducing unnecessary loss of water (Narayanamoorthy, 2004). Most of the Farmers of Dhading applied organic manure to acclimatize with declining soil fertility as it improves soil properties (Pyakurel et al., 2019). Crop residue retention improves soil fertility (Jangam and Rupa, 2017). Increase in $\mathrm{CO}_{2}$ and temperature lead to increase in population of pest and severity of disease, provided that host plant is available (Malla, 2008). New type of diseases had been seen, they might be migrated from terai (Malla, 2008). Burning crop residue may reduce soil borne disease to some extent (Bailey and Lazarovits, 2003) but burning crop residue is detrimental to environment as they emits trace amount of gases like $\mathrm{CO}_{2}, \mathrm{CH}_{4}, \mathrm{~N}_{2} \mathrm{O}$, $\mathrm{SO}_{2}$ and large amount of particulates (Vats, 2015). Higher dose of agrochemicals pose serious threat to environment which further accelerates climate change (Bhandari, 2014). The gender of household head, membership of farmers group, and access to extension agents help farmers to adopt new technology of agriculture (Dahal and Rijal, 2019). 


\section{CONCLUSION}

This study analyzed perception and impact of climate change among vegetable growers in Dhading district of Nepal. Different farmers perceived their idea differently about climate change. This study showed that the incidence of disease and pest, decline in soil fertility, scarcity of water and severe frost/hailstones are major problems. Climate change forced farmers to change planting and harvesting time. The mulching, green/plastic house, drip irrigation, IPM, change in crop variety and cropping pattern are some adaptation practices to mitigate climate change effect. It would be better to suggest policy makers, other authentic bodies and farmers to introduce new climate smart agricultural technologies. Providing training about vegetable cultivation helps farmers to get rid from the negative impacts of climate change.

\section{REFERENCES}

Bailey, K.L. and Lazarovits, G. (2003). Supressing soil-brone disease with residue management and organic amendents. Tillage and Soil Research, 72: 169-180.

Basyal, R. (2017). Climate change impact in water resources: A case of Nepal. Retrieved from climatetraker.org: http://climatetracker.org/climate-change-impacts-waterresources-case-nepal/

Bhandari, G. (2014). An overview of agrochemicals and their effect on enviornment in Nepal. Applied ecology and Enviornmental Science, 2 (2): 66-73.

CBS. (2011). National Population and Housing Census 2011. kathmandu, Nepal: Government of nepal, national Planning Commision Secretariat, Central Bureau of Statistics.

Dahal, B.R. and Rijal, S. (2019). Production economics and determinants of potato productcion in Nuwakot, Nepal. International Journal of Applied Science and Biotechnology, 7 (1): 62-68.

Devkota, R.P. (2014). Climate Change: Trends and People's perception in Nepal. Journal of Environmental Protection, 5: 255-265.

Dhakal, P., Shrestha, N.S., Shrestha, M.L., Krakuer, N.Y., Panthi, J. and Pradhanang, S.M. (2016). Drought risk assessment in central Nepal: temporal and spatial analysis. Natural hazards, 80 (3): 1913-1932.

Gaire, S., Delgado, R.C. and Gonzalez, P.A. (2015). Disaster risk profile and existing legal framework of Nepal: Flood and landslide. Risk Management and Healthcare Policy, 8: 139-149.

IPCC. (2007). Climate change 2007: Impacts, Adaptation and vulnerability. Cambridge University Press.

Jangam, D. and Rupa, B.D. (2017). Crop residue and its influecne on soil properties. Bulletin of Environment, Pharmacology and life sciences, 3: 68-71.

Karki, M., Mool, P. and Shrestha, A. (2009). Climatr Change and its Increasing Impacts in Nepal. The Initiation, 3: 30-37. 
Karki, R., Shabeh, H.U., Schickoff, U., Scholten, T. and Bohner, J. (2017). Rising Precipitation extremes across Nepal. Climate, 5(1): 4.

Liao, T.F. (1994). Interpreting probability models: Logit, probit and other generalized linear models. Thousands oaks, California, USA: Saga publications.

Malla, G. (2008). Climate change and its impact on nepalese agriculture. The Journal of Agriculture and Environment, 9.

Malmqvist, C., Wallertz, K. and Johansson, U. (2018). Survival, early growth and impact of damage by late-spring frost and winter desiccation on Douglasd-fir seedling in southern Sweden. New Forests, 49: 723-736.

MoAD. (2017). Statistical Year Book. Thapathali, kathmandu: Government of Nepal, National Planning Comission, Central Beureau of Statistics.

Narayanamoorthy, A. (2004). Drip irrigation inIndia: Can it solve water scarcity? Water policy, 6 (2): 117-130.

Pandey, G., Basnet, S., Pant, B., Bhattarai, K., Gyawali, B. and Tiwari, A. (2017). An analysis of Vegetables and Fruits Production Scenario in Nepal. Asian Research Journal of Agriculture, 6 (3): 1-10.

Pyakurel, A., Dahal, B.R. and Rijal, S. (2019). Effect of molasses and organic fertilizer in soil fertility and yield of spinach in khotang, Nepal. KInternational Journal of Applied Science and Biotechnology, 7 (1): 49-53.

Sapkota, R. and Rijal, K. (2016). Climate change and its impact in Nepal. Institute of Science and Technology, Tribhuvan University, Central Department of Environmental Science, Kritipur, kathmandu.

Subedi, A.P. (2018). Effect of climate change in mountaineous agricultural system of makawanpur, Nepal. Jouranal of Agriculture and Forestry University, 2: 35-44.

Uzunoz, M. and Akcay, Y. (2012). A case study of probit model analysis of factores affecting packed and unpacked milk in Turkey. Economics Research International .

Vats, N.K. (2015). Crop residue burning is deterimental to environment. International Journal of law and Legal Jurisprudence Studies, 2 (1). 